\title{
オフィス情報管理システム機能の高度化
}

\section{Advanced system functions for the office information system}

[著者抄録］はじめに，オフィス情報管理システムの機能について考察し，次に，システム 機能の高度化を図る上で必要な要件について検討をする。システム機能の高度化の検討は, 例 えば, データの処理時間, 処理経費の削減策等, あらゆる観点から総合的にとらえる必要があ るが, 本論では, システムの利用者であるオフィス・ワーカにとって，いかに“使い勝手の良 いシステム”にするかという，いわゆる，マン・システム・インタフェイス（ヒューマン・イ ンタフェイス）機能の高度化の観点から検討をする。

[著者付与キーワード］ オフィス情報管理システム, 情報管理システム, マン・システム・ インタフェイス, ヒューマン・インタフェイス, 社内データベース, 情報検索, データベース 構築

[Author Abstract] First, author describes the functions needed for information management system in office. Next, he mentions the requisites for the enhancement of system functions. In order to make enhancement of system functions, he states, it is necessary to examine them comprehensively from every point of view including processing hour and cost. In this paper, he concentrates on the enhancement of man-machine interface (= human interface), that is, how to make system easy to use for the office workers.

[Keywords by Author] office information system, information management system, man-system interface, human interface, in-house database, information retrieval, database construction

* 目書館情報大学 図書館情報学部

（テ305 茨城県つくば市春日1丁目2番地） Tel。0298(52) 0511(内線332) University of Library and Information Science ( $1-2$, Kasuga, Tsukuba-shi, Ibaraki-ken, 305) 


\section{1. オフィス情報管理システムの機能}

\section{1 情報活用形態と対象情報}

図 1 に示すように，企業等組織体における情報 活用形態を大別すると，3 形態に類別できる。「定 常業務処理のための情報活用」は，組織管理（例 之ば，人事管理）および既存の製品あるいは商品 により利潤を追及する過程の業務処理（例えば， 会計処理）において必要となる一切の情報活用で ある。「新規事業を企画・立案するための情報活用」 は，新規事業を起業化する過程（例之ば，研究・ 開発)において必要となる一切の情報活用である。 「意思決定のための情報活用」は，以上の 2 件の業 務処理結果として報告された情報を元に，経営上 の意思決定を行う情報活用である。オフィス情報 管理システムは，この情報活用を円滑に行えるよ う電算機システムを中心として組織化した機能で ある。

情報は，情報伝達媒体およびコミュニケーショ ン内に内在し，その内容を認識したときに情報と して確認されるものである。情報活用のために， これら情報伝達媒体の管理およびコミュニケーシ ヨンの内容の媒体への変換（=記録化）およびそ の媒体の管理が必要になる。

情報伝達媒体には，ドキュメント（例：資料・ 文書等)，機械可読媒体 (例 : 磁気・光媒体等) 抢よ び機器内情報ファイル（=データベース）がある。 それぞれの情報伝達媒体への情報表現形式（=記 述形式）により，例之ば伝票，報告書等に類別さ
れる。情報活用とは，これら情報伝達媒体の内容 を業務の目的に照らし，認識し，利用する行為で ある。業務処理とは，情報伝達媒体の内容を業務 の目的に照らし処理する行為であると理解でき る。

業務処理には，その目的の完全達成と合わせ， そのために掛かる時間，経費，質の効率性が求め られる。この目的の完全達成と効率性に，職員の 業務処理能力と合わせ，オフィスにおける情報提 供の支援機能がかかわってくる。

本稿では, 後者の情報提供システム機能をオフ イス情報管理システムの範疇としてとらえ，その 機能および高度化機能について以下で検討をす る。

\section{2 情報提供システムの機能}

情報システム機能を，職員に情報伝達媒体デー 夕に関するデー夕を提供するための『情報伝達媒 体デー夕提供システム』と, 情報伝達媒体の内容 そのものを提供するための『情報提供システム』 の 2 系列に大別してとらえることができる。

図 2 に示すように，前者については，従来，フ アイリング・システム（以下，FS という）として 実行されてきたが，近年，電算機システムを中心 としてオフィス情報管理システムの構築が可能に なったことから，後者について，特にオフィス・ オートメーション (以下，OA という)の確立を目 標にシステム (以下 OIMS : Office Information Management System という）の構築・運用が図

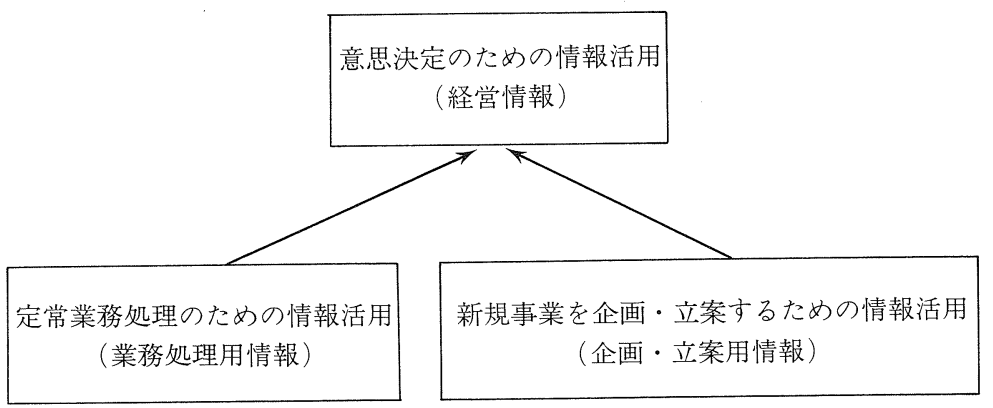

図 1 企業における情報活用 


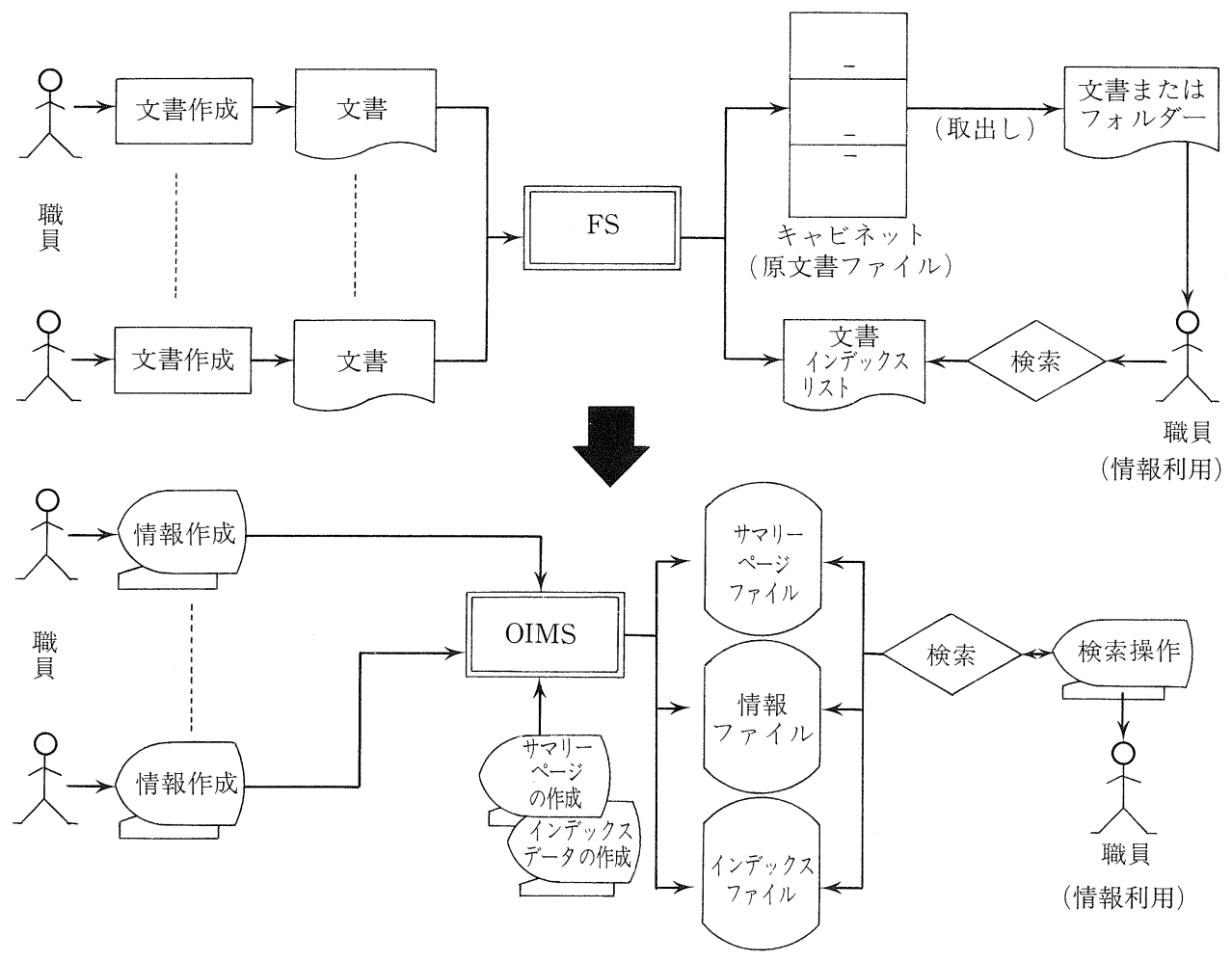

図 2 情報管理の $\mathrm{OA}$ 化対応

\section{られるようになっている。}

FS 下での情報活用は，情報伝達媒体をファイ リングされている場所に出向き，利用しなければ ならず，当然のこととして情報へのアクセス効率 は極めて悪いものとなる。それに対して，情報提 供システムでは, 全社レベルの, しかも広域の不 ットワーク・システムの実現により，オンライン・ リアルタイムでの情報へのアクセスが可能である ことから，その効率は極娘いものになる。さ らに，情報提供システムをデー夕処理システムと 統合し，稼働させることにより，情報内容解析お よび情報を生成する機能の実現により，知識情報 の操作が可能になり，戦略的情報システム（Strategic Information System) として確立させるこ とが可能になる。
しかし，情報伝達媒体の内容をすべて情報ファ イルに蓄積し，運用に供することについて，現時 点において技術的に可能ではあるが，処理時間， 運用経費等の効率からその実現は困難であると言 わざるを得ない。そこで，現時点において，最も 現実的な，しかも将来に向けて拡張性のある OIMS 機能を考えなければならない。

以下，情報伝達媒体に関するデ一夕を中心に利 用に供するOIMSの機能について考える(図 3 )。

(1)情報ファイルの構築

情報伝達媒体は，オフィス外において作成され オフィス内に持ち込まれるもの（一般に，その内 容を外部情報という）と，オフィス内において作 成されるもの（一般に，その内容を内部情報とい う）に大別できる。 


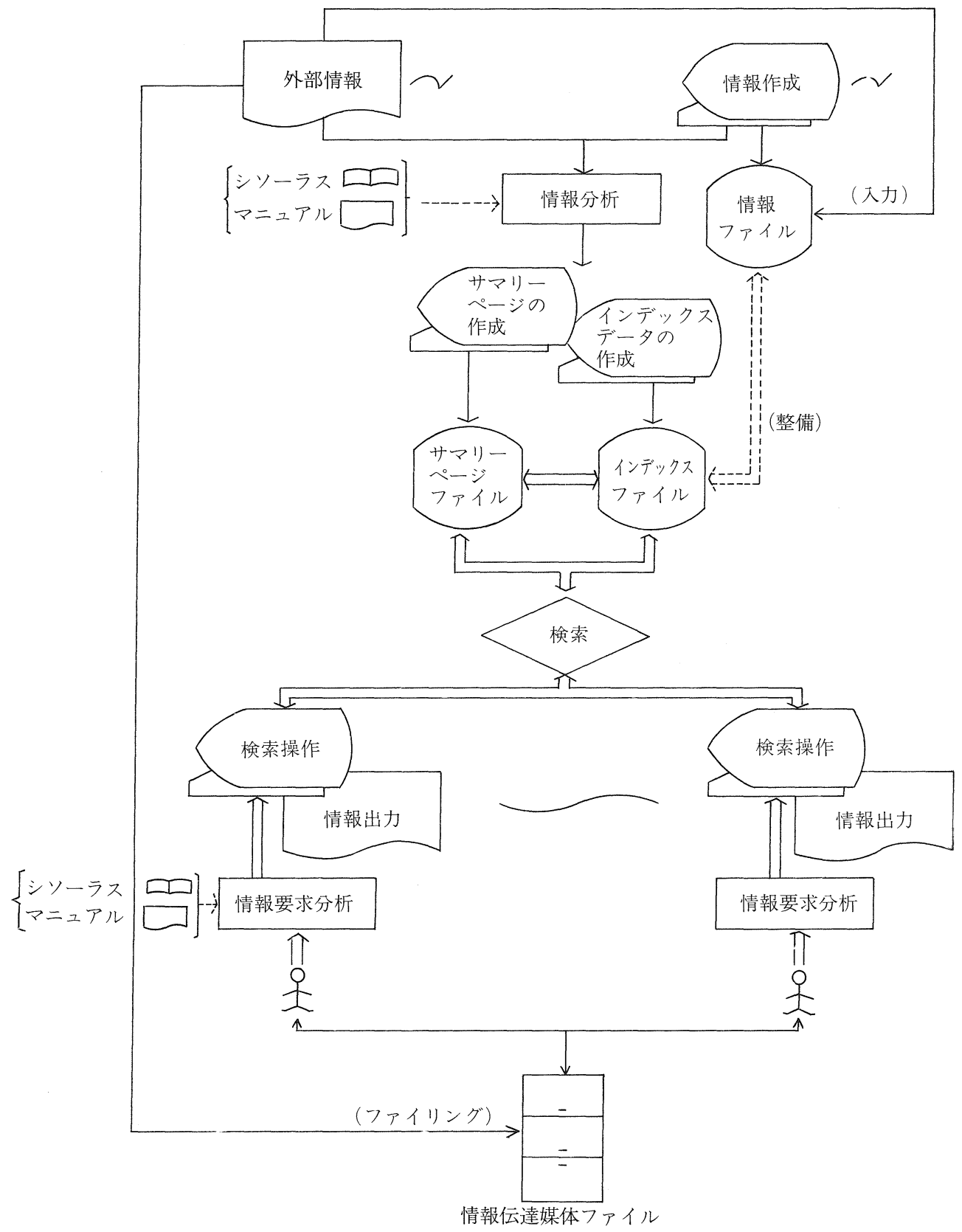

図 3 オフィス情報管理システム(OIMS)の機能 
外部情報伝達媒体については，必要に応じ情報 内容すべてを情報ファイルに蓄積する必要のある ものと必要のないものに, ある情報管理規定によ り類別する。ただし，いずれにしても，情報伝達 媒体は，オフィス内に，例えばファイリング・セ ンターのような部門を設け，そこで保管する（た だし，ファイリング・センターは，単なる情報伝 達媒体保管部門とするだけではなく，例えば，印 刷あるいは媒体変換等を行う複合機能を持たせ る)。

内部情報については，原則として，OIMSのオ ンライン端末機のワードプロセッサ（以下，ワー プロという）機能の使用により作成し，すべてを 情報ファイルに直接, 蓄積する。コミュニケーシ ヨン時の内容も, この系により情報ファイルに蓄 積する。現時点では, 情報ファイルの媒体は, 磁 気ディスクおよび光ディスクが利用できる。

(2)インデックス・デー夕およびサマリー・ペー ジ・ファイルの構築

前述の情報ファイルには，原則として情報内容 がすべて蓄積されることになる。しかし，特に文 章で表現されている情報については，現時点の技 術では，文章内容を完全に自動解析し，その結果 を利用し検索を行うことは不可能であることか ら, さらに, 検索結果の一覧性の利便性から, 情 報ファイルを直接, 検索処理対象ファイルとして 利用することはできない。

そこで, 情報単位に, 情報に関するデータ(イ ンデックス・データ）およびその内容を紹介する データ（サマリー・ページ）を作成し，それぞれ のファイルを構築し, 前者を検索処理対象ファイ ル（インデックス・データ・ファイル）として位 置づけ, 後者を情報概要紹介ファイル(サマリー。 ページ・ファイル）として位置づけ，利用に供す る。

このために，外部情報伝達媒体入手者は，情報 内容について分析を行い，インデックス・データ

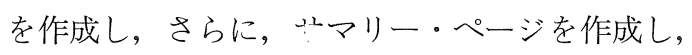
それぞれのファイルに構築する。また, 内部情報 に関し,コミュニケーション時の内容や業務上発
生した情報について，オリジナル情報の作成と同 時に, インデックス・データ・ファイル, サマリ 一・ページ・ファイルを外部情報伝達媒体の扱い と同様に構築する。これらデータの作成とファイ ルの構築には，全社レベルで例えばフォーマット 等の統一化が必要になる。そのために, 情報管理 規定の一部として，マニュアル等を用意し，また， 標準化の下で運用できるよう社員教育を実施す る。

(3)情報検索

情報要求者は, インデックス・データ・ファイ ルに対する検索実行の後, サマリー・ページ・フ アイルを一読し，必要に応じて，情報ファイル内 の情報を利用する。情報ファイルに取り込まれて いない情報に関しては, 情報伝達媒体を利用する。

以上の機能は, まさに, OA システムそのもので ある。当システムの運用により, 例之ば, 在宅勤 務, サテライト・オフィスの運用も可能になる。 当システム機能は, 電算機システムや通信ネット ワーク・システムの技術により, 構築は十分可能 である。

しかし，製品の生産管理のオートメーション・ システム (Factory Automation System) のよう に, OA システムは, 社員のシステムへの参加がな されず，実際には運用に移行できないことにより 促進されていないのが現状である。その最大の原 因は，オンライン端末機に“馴染めない”という 問題とシステムの“利用の繁雑さ”にある。

この意味から，当システムの運用の実現には， 両者の問題点を技術的に解決しなければならない 多くの課題が，まだまだ存在していると言える。 要は，いかに“使い勝手の良い”システムにする かという，いわゆる，マン・システム・インタフ エイス（ヒューマン・インタフェイス）機能の研 究が必要であると考える。 


\section{2。 システム機能の高度化を図る上で必要な要件}

\section{1 マン・システム・インタフェイス機能の研} 究の必要性

OIMS の構築・運用の最大の目的は，オフィス 業務の効率の向上のために，オフィスにおいて， 情報へのアクセスの “距離の差と時間の差”を克 服する機能を職員に提供することにある。そのた めには，職員に“使い勝手の良い”システム機能 を提供しなければならない。システムの使用に関 する“使い勝手の良さ”を追及する対象機能は， 情報ファイルをはじめインデックス・データ・フ アイルおよU゙サマリー・ページ・ファイル（以下， 3 種類のファイルを総括して，オフィス内データ ベース，略して，DBという)の構築および DB のアクセス操作を行うインタフェイス機能であ る。その理想的な機能化は，完全自動化である。 特に，職員の年齢差・人種差を超え使用できるシ ステムにする必要がある。

DB 構築および検索に関するシステム機能は, 基本的には，データべース管理システム(DBMS) のソフトウエア機能にある。DBの構築のための データ入力操作機能については, 特に, 最近では, ワークステーション (Work Station, 以下，略し て，WSという）レベルで利用可能な高度編集 (Desk Top Publishing, 以下, 略して, DTP と いう）システムが提供されるようになってきてお ク，また，検索機能についても，情報内容の全文 （フル・テキスト）を対象に，直接，検索可能なシ ステム機能が出現してきており，技術的実現が図 れるようになってきた。

そこで，特に，DB 構築のためのデー夕入力操 作，検索操作のためのシステム機能を中心に，改 めて “使い勝手”の観点から，その高度機能化を， システムの利用者の立場に立って，現時点で実現 可能な支援機能と研究・開発を必要とする機能に 分け，その幾つかについてマクロ的に検討を試み る。

\section{2. $2 \mathrm{DB}$ 構築のための支援機能}

(1)実現可能な支援機能

(1)“読み”を残すワープロ機能

インデックス・データ・ファイルは，検索処理 用ファイルである。インデックス・デー夕は，検 索キーとの照合を可能とするために EBCDIC コ 一ド系と, 出力表示のための漢字コード系のデー タをパラにインデックス・データ・ファイル内に 作成しておかなければならない。検索キ一の指示 は，オンライン端末機のキーボードからなされ， その入力コードは, EBCDIC コードということに なる。

現在あるオンライン端末機のワープロ機能を利 用して作成するには，漢字コード系のデータ作成 を行い，同一のデー夕に対して，改めて EBCDIC 系のデー夕を二重に入力しなければならない。こ のことは，入力操作に 2 倍の負荷が掛かるのと同 時に，インデックス・デー夕に正確性が要求され ることから，そのデータ・チェックにより，入力 者の眼性疲労の要因にもなる。このことの回避の ためには，漢字コード系のデー夕作成と同時に EBCDIC コード・デー夕を作成できる，すなわち， “読み”を残すワープロ機能の実現が必要になる。

(2)文字相互変換機能

入力時のデー夕表現は，ローマ字または仮名と いうことになる。ローマ字表記には，へボン式， 一般訓令式，法令式の 3 通りがある。我々，日本 人の日常の社会生活においては，へボン式が一般 的である。しかし，法律では，法令式口一マ字使 用が定女られている。故に，人によりこの 4 通り の表記に対し習熟性が異なる。

しかし，現在，提供されているワープロ機能で は，ローマ字表記の 1 系列と仮名入力に限定され ており，このことは，キーボード使用上の習熟性 から，全社員に対して 2 系列のみの入力方式を押 し付けることになり，使い勝手の観点から考える と問題になる。

このことに対して，拡張して，4 通りの表記に よる入力法を保障することが理想である。そこで, 4 通りの表記から 1 系列表記への文字変換機能が 
必要になる。また, 法令式ローマ字表記のデー夕 を作成したり，法令式ローマ字表記の DB を社外 から移入し，利用することが発生することから， この機能が必要になる。

(3)オーソリティー・データ・ファイルの維持と データ取り込み機能

人間同志が行うコミュニケーションの内容を, そのままの表現で DB 内に蓄積はできない。例え ば，専門用語等の記号化表現・短縮形表現は，正 規の表現の用語も DB 内に持たなければ検索に供 せない。これら表現を，入力者がそのつど，調査 し，大力するのでは負荷が大きくなる。

そこで，記号化表現・短縮形表現デー夕を入力 し，それに対応する正規表現のデー夕を発生でき る大規模なオーソリティー・データ・ファイル（例 えば，一種の用語集）を位置付け，そこからデー 夕を取り込み，正規表現のデー夕を生成する機能 化が必要になる。

また，同一の表現のデー夕を，すべて改めて入 力するのではなく, 例えば社内の場合には, DB 内 のデータを相互に利用し合い，DBの作成のスピ 一ド・アップを図る運用が大切である。このこと は，一般には，著作権に代表される知的所有権の 問題を派生させるが, 社内の DB 利用においては, 問題は起こらないはずである。そこで，同一のデ 一夕については，簡略キーによる検索により，既 存の DB からの自動推定によるデータの取り込み (down loading / up loading) 機能が必要になる。

(4)ワープロ用ユーザ辞書の辞書管理機能

メーカから提供されるワープロ用辞書は, 基本 語を中心とする約 6 万語の辞書であり，各オンラ イン端末機に用意されているユーザ辞書領域も少 なく, 特に業務上発生する専門用語の保有には十 分対応できない。また, 各オンライン端末機のユ 一ザ辞書領域に，各人が個別にユーザ辞書を維持 しても，用語のオフィス内における統一を保障で きない。

そこで，上記のオーソリティー・データ・ファ イルとも一体化させ，センター・マシン内に大規 模な辞書を構築し, 利用に供し, 各オンライン端
末機の辞書を補完させながら利用できる機能化が 必要になる。そのためには, オーソリティー・デ ータ・ファイルの維持管理と合わせ, ワープロ用 ユーザ辞書の管理の機能化が必要になる。

(2)研究・開発を必要とする支援機能

(1)情報内容の自動解析, インデックス・データ・ ファイル/サマリー・ページ・ファイル自動生成 機能

すべての情報に対して，業務処理を遂行する中 で，職員一人一人がインデックス・データ・ファ イルおよびサマリー・ページ・ファイルを作成す るのは，実は大変であり面倒であることから， OIMS は技術的に構築できても運用に供せない 最大のネックになっている。このインデックス。 データ・ファイルおよびサマリー・ページ・ファ イルを自動的に構築するためのシステム機能の実 現が必要になる。それには, 情報内容の自動解析 を行い, インデックス・データ・ファイルの自動 生成（自動索引）およびサマリー・ページ・ファ イルの自動生成 (自動抄録) の機能開発が必要に なる。

\section{(2)情報表現の自動言語変換機能}

情報は，日本語表記のものだけとは限らない。 国際化が進む中で, 少なくとも英語表現の情報は， 日本語による情報と差異を感じることなく利用・ 作成できなければ，日常業務に対応できなくなっ てきている。しかし，このことは，容易なことで はない。そこで, 情報表現の自動言語変換機能(機 械翻訳システム)が必要になる。この実現により， DB 内に多言語表記の情報を同時に維持すること が可能になり，情報活用においても，言語の差異 を感じることなく利用できることになる。

(3)データ・チェック／修正機能

DB 内のデー夕は正確に記述されていなければ ならない。しかし，キーボードによる入力ミス， さらには業務処理内において発生するミス（この 結果は, 情報自体の䛊りとなる) は, 人的問題と して避けられない。そこで, 人的ミスを補完する ための機能として，データの物理的（例えば，デ 一夕の記述形式), 論理的(例えば, データ項目間 
の関連）チェックの機能以外に，下記のようなデ ータ・チェック／修正機能が必要になる。

a）必須デー夕項目の入力デー夕・チェック機 能

検索対象デー夕項目に対応する DB 内のデー 夕項目（必須デー夕項目という）には，必ず何 等かのデータが入力されていなければならない (その他のデー夕項目は情報表示用デー夕項目 である)。データ入力時に，DBへデー夕転送す る時に, 必須デー夕項目の内容をチェックし， 転送拒否および警告を発生させる機能が必要に なる。

b）スペリングおよびデータ表現の正規化チ工 ック/修正機能

スペリング・チェック／修正機能は，誤字・ 脱字に対するチェック／修正機能であり，デー 夕表現の正規化チェック／修正機能は, 特に, 文章表現データの文法の誤りと意味上の曖昧性 をチェックし，自動的に修正する機能である。

\section{3 情報検索のための支援機能}

情報検索の内容をオンライン端末機に指示する 際に，データ入力の容易性についてのシステム機 能の問題が発生するが，このことについては，前 項と同一の検討内容になるのでここでは改めて述 べない。

(1)実現可能な支援機能

(1)画面型検索内容指示方式機能

情報要求者が“構える”ことなく，気軽に，検 索内容を指示できる機能の提供が大切である。そ れには, 情報要求者が, 情報要求内容をオンライ ン端末機に，必要な検索内容を表現できるような 検索内容指示画面を用意する必要がある。情報要 求者が, 情報要求内容を, この画面内の検索項目 に対し検索キーを指示すれば，後は自動的に検索 に行く機能化である。

(2)関連情報を検索する機能

情報要求者が指示した検索キーとその表記形態 だけの検索機能では，検索結果を見ながら再度何 回も検索キーを指示し直すことになる。そこで,
一度指示した検索キーを元に，関連情報を検索す る下記の機能化が必要になる。
a）検索キーの自動制御・検索機能

指示されたすべての検索項目内の検索キーが インデックス・データと一致しなければ, 検索 要求に相当する情報として見なさないというの ではなく，一致しなければ一つずつ検索項目内 の検索キーを落として検索する機能。

b) 関連検索キーの検索機能

指示された検索キ一に対して, 例えばシソー ラスを用いることによって，シソーラス内のあ るカテゴリ範囲において，その中にエントリー されている関連語に対し検索する機能。

c）検索キ一内の部分要素による検索機能 いわゆるトランケーション検索機能。特に, 前方一致, 後方一致に対して, 中間一致機能の 実現を必要とする。

(3)検索結果の出力先指示および編集機能

検索結果をいろいろな先に転送したり，あるい はいろいろな媒体に出力をすることが生じる。こ のことに応じられるよう機能化することと, 必要 なデー夕項目のみを出力したり，各種フォーマッ トに編集できる機能が必要である。

(2)研究・開発を必要とする支援機能

(1)情報内容自動解析・検索機能 前項(2)の(1)でも述べたように，インデックス・ データ・ファイルおよびサマリー・ページ・ファ イルを介さず，情報ファイルそのものの内容を直 接，検索できることが理想である。そのためには， 検索要求内容も文章形式で発行し, その内容を自 動的に解析し, 検索できる機能の実現が必要にな る。

\section{(2)ファクト (知識データ) の自動抽出}

情報ファイルの内容をそのまま検索結果として 出力するのではなく, 情報ファイルの内容を解析 し，必要とするデータ（ファクト・データ）のみ を出力する機能が必要になる。

(3)情報表現の自動言語変換機能

(1)と同様に，前項(2)の(2)でも述べたように，検 索結果の機械翻訳システムによる自動言語変換機 
能が必要になる。

以上の機能の実現には，文字自動認識，自然言 語処理, 図形情報処理等の基礎研究の成果が待た れる。

\section{4 マルチ情報ファイル（MDB）化機能}

情報の記述表現形式に, 文章表現, 図形表現法 があり, 情報伝達媒体内に混在し表現されている。 DBの構築に当たり，図形情報は当然のこととし て無視はできない。また検索においても，図形内 の情報を対象に検索する機能が必要になる。図形 も対象にDB化および検索する機能について MDBの技術が確立されてきている。そこで, 社内 情報システムの構築に必要な機能について以下で 示す（音声表現情報については除いて考える）。

(1)実現可能な機能

(1)図形の入力 (DB 化)

情報伝達媒体の内容をすべて入力するのに，キ 一ボードによるパンチ方式では，時間や経費効率 は大変悪いものになる。そこでイメージ・スキャ ナ一の利用が必要になる。イメージ・スキャナー の利用により，図形情報をイメージ・データとし て情報ファイル内に構築する。

(2)図形情報用インデックス・データ・ファイル の構築

図形情報の紹介デー夕を，インデックス・デー タとして作成し，インデックス・データ・ファイ ルを構築し, 検索用ファイルとして利用に供する。 検索には，今まで述べてきた検索キ一の指示によ $\eta$ ，図形情報のみを対象に検索処理する機能化に より検索は可能であり，検索結果をイメージ・デ ー夕のまま出力すればよいということになる。

(2)研究・開発を必要とする機能

(1)図形情報用インデックス・データ・ファイル の構築と検索

上記の方式では，図形情報の特徵を分析し，イ ンデックス・データとして表現しなければならず， この場合，図形情報の特徵をすべて忠実に表現し 得るかという問題が起こる。そこで，図形を構成 する“フレーム (画素)”をインデックス・データ
とする方式の機能化が必要になる。このフレー ム・インデックス・データの検索には，フレーム を，情報要求者が，例えば，イメージ・スキャナ 一に対して直接スケッチをして，そのスケッチ画 からフレームを切り出し，フレーム・インデック ス・データと照合し，検索するシステムの機能化 が必要になる。

\section{3.おわりに}

最近, 東京大学の坂村健助教授の提唱する「電 脳都市」構想の実験プロジェクトが話題になって いる。この構想の根底にあるものは，人間のとる 行動に対して，システムがすべて感応し，移住空 間の環境とファシリティ（主に設備）を制御する 機能の追及にある。この結果，人間のとる行動に 対して，常に最適な環境が提供され，またこの結 果として, 行動の目的を完全に, 効率良く達成で きることを支援するものと理解できる。このシス テムの実現には，移住空間の環境とファシリティ のすべてについて，その特性をDBに維持するこ とが必要であることが推測できる。

OIMS の理想とすることも, 社内の業務処理に 必要とする情報およびデー夕を, すべてシステム が処理・管理することの機能化であると理解でき る。情報およびデー夕に対する処理の指示は，業 務の目的により職員がシステムに対して行うこと になり，その指示する内容を判断し，またこのシ ステムから得るという使用形態になる。

例えば，米国で見聞した例であるが，出張旅費 の請求を，オンライン端末機の画面に請求伝票を 呼び出して行ったり（もちろん，請求された内容 は，いったん DBに転送され，会計担当が定期的 にDB を検索し，判断を加え，後に自動的に給与 計算処理され，銀行振り込みを行う一貫したシス テムが背景で動いている), 出張報告書を同じくオ ンライン端末機上で作成し, DBに転送し，その内 容に対するレスポンスは，端末機に返ってくる， といった運用がなされている。

本稿の中で述べたことであるが，このようなシ 
ステム機能の構築は，技術的には可能である。こ のようなシステム機能による運用を行うのがよい のかどうか, その判断には, 例えば，この様なシ ステム機能を駆使して行う, 就業上の快適性に代 表される他の要因について検討を加えなければな らないが，我が国において，このようなシステム を，トータル・システムとして運用している例は 皆無と考える。

その最大の要因は, “端末機の操作に対する馴染 みの問題”にあり, 今の時代は, 就業者の年齢層 から見て過渡期の時代にあると言える。この要因 の回避のためには, 利便性の理解教育の実施と, いかに“使い勝手の良い”システム機能にするか という課題がある。本稿では, 後者の課題につい て，システムを操作する側からとらえ，利用上の 観点から幾つかの機能について考察を行った。

OIMS の運用を実施する上で，もう一つ考えて おかなければならない問題がある。情報は無限の 資源として管理しなければならないことに対し て，それを中心的に維持する電算機システムは有 限の資源であることから, 情報管理者を位置付け, その権威の下で情報資源のメンテナンスを厳格に 行うことをしなければならない，ということであ る。

また，知的所有権の問題が厳しく問われてきて いることおよび業績に対するディスクロジャーを
明確に行うためにも，社内の情報資源の管理を厳 密に行うことがますます必要になってきている。

このことに対して，欧米の企業において，情報 管理者 (Office Information Managerまたは Engineer) の職能あるいは職種が明確になりつつ ある。同じく米国での見聞として，その情報管理 者は，情報管理取締役部長として，DB 内の情報， 特に，報告書を対象に，出力を行うことの判定お よびその配布先についての決定権を持つ任のある ことの説明を受けたことがある。要は, 情報管理 に，取締役部長クラスが行うことの重さを理解す る必要があるということである。

\section{参 考}

1）この稿を起すに当たって，WSを中心に， DBMS, DTP, ワープロ, 光ファイリングシステ ム等，製品カタログを収集し，利用した。ソフト ウエア機能の最新の動向の把握には, 日頃から利 用している情報源(『日本情報産業新聞』, 『日経産 業』, 『日経コンピュータ』)の切り抜き記事を利用 した。

2）その他には，主に，下記のものを閲覧した。 『データベース白書』（データベース振興センタ 一発行), 『通信白書』, 『科学技術白書』, 『科学技 術情報ハンドブック』(日本科学技術情報センター 発行)。 